\title{
THE LEGAL PURPOSES OF WOMEN'S EMPLOYMENT
}

\author{
${ }^{1}$ Mohammed Muqbil Nasser Al-Muqbil \\ ${ }^{1}$ Assistant Professor, Department of Islamic Studies, College of Education, Prince Sattam bin Abdul-Aziz University, Kharj \\ 11942, Saudi Arabia m.almqbl@psau.edu.sa
}

\begin{abstract}
The current era's developments require the expansion of research into the goals and purposes of Sharia when tackling social challenges in the Muslim world; especially in the issues currently under discussion and controversy, which is women's work. In the research that we have here, a presentation that accompanies these developments and that deals with the desired purposes of women's work comprehensively, showing the concept of women's work through the goals of the Sharia, illustrating the deep connection between the concept of the work in question and preserving the five essential goals of the Sharia: Preserving religion, facilitating education, protecting human life, preserving one's honor and one's wealth. The author then went on to observe these goals in the matter of women's work, in terms of preventing harm, achieving justice, balancing benefits and harm to society, and discussing the outcomes of women's work, such as the doing of good, contributing to society, maintaining good societal manners, and obtaining the best education for one's dependents. Then he concluded with the writing's most prominent results and recommendations.
\end{abstract}

Keywords: Discrimination, goals, Islam, Islamic law, Sharia, sexism, work, women

Article Received: 18 October 2020, Revised: 3 November 2020, Accepted: 24 December 2020

\section{Introduction}

Praise be to Allah, Lord of all creation, and prayers and peace be upon the Prophet Muhammed, his family, companions and followers. To proceed:

Wise people agree that a woman's relationship with the economy and with financial transactions is related to the extent of her participation in it, and the resulting economic benefits for women and society in terms of economic stability and societal well-being, and this view is based on what Islam decides about a woman's right to property and the permissibility of her actions in social life within Islamic regulations.

However, this deep vision does not converge with those who narrow the circle of women's participation in social life and do not see them having the right to go beyond the walls of their homes as well as to contribute to the development of society and the prosperity of the nation's economy.

It is an approach that is inconsistent with Islamic law and its perfection, which takes care of women as well as men, and it placed the responsibilities of education and societies heavily on their shoulders.
Also, those who oppose women's work waste a lot of the potential of women and their experience. Therefore, it is necessary to overcome these negative approaches and deal with women's issues in accordance with the legal implications and requirements involved, especially in the field of work. This study will focus on the legitimate purposes of women's work according to the texts of Revelation.

\section{Theoretical Framework}

The following questions determine the problem to be addressed: What are the objectives of women's work in Islamic law? Does a woman's work positively or negatively affect the family strength? What is the objective of women going out to work?

This study has several objectives, most notably: To explain the holistic view of the Sharia towards women and highlight their role in the economic field of society. And to determine the intentions of the legal provisions related to the work of women. The significance of the topic is summarized in explaining the legitimate objectives of a woman's work according to the texts of the Qur'an and 
Sunnah in an analysis, a deduction and furthermore its specificity.

\section{Methodology}

The research work is carried out on the basis of the descriptive method, in its inductive and deductive aspects.

\section{The Definition of the Work of Women} and the Objectives of Sharia

A definition of women's work is: The participation of women in the service of society due to the benefits that accrue to her and achieving the interests of society as a whole.

The work of a woman in her home is considered to be a part of the concept of working in society, and this is a broad and correct concept, as the basic job of a woman is to correct and maintain society by firstly carrying her offspring, giving birth, and taking care of her children in order for the life cycle to be complete; so everyone is facilitated to what he has been created for.

Principled [Maqaasidy] science, in Arabic, is the knowledge of a set of intentional criteria and rules that include general meanings drawn from the goals that the Sharia came to achieve, applied by hardworking members of the society in juristic and emerging issues, in order to issue legal rulings that achieve the purposes of Sharia.

The definitions of contemporary scholars have been identified at a merging point for a comprehensive definition of Sharia objectives, and the best of these definitions from the researcher's point of view is: "The applicable meanings of the religion of Islam when rulings are passed to achieve the interests of the Sharia and society as a whole." 1

5. The Work of Women and its Relationship with Preserving the Five Essential Purposes of the Sharia

\subsection{The First Necessity - The Objective of Religious Preservation}

The basis of Islam lies in faith in Allah and the doing of good deeds, and the mission of a Muslim woman is to preserve this religion by establishing its features in herself and then teaching and advocating for them. The impact of women's work in preserving religion is shown through the following branches:

The Purpose behind the Worship of the Creator and Legislator and Submitting to the Legislative Texts

Allah created man to worship and obey him, and Allah provided him with wealth and sustenance to help him do so. So the successful ones are those who allowed their money to help them in achieving those pursuits: To obey Allah, and to help him in that which benefited him in his living. The losers are those who used their wealth solely for their own desires and immediate needs. Therefore, Allah did not make the supreme destination of the purified law, requesting and accumulating money, nor the ultimate goal, instead, it is a means to strengthen the obedience and worship of Allah, and an instrument by which the worshipper connects to what is in his possession.

Bringing the person in charge out of his own desires is a legitimate objective, as the continuation in meeting the whims of the soul is accustomed to working to satisfy himself without commitment to the provisions of the Sharia and its directives, until this leads to encroaching the prohibitions of Islam and to a leniency in committing them.

It is an obligation that all actions are disciplined by Sharia teachings, commands, and interdictions. These obligatory devotions are one; the obedience to the Command of Allah and His Messenger is obligatory for males and females: "It is not for a believer, man or woman, when Allah and His Messenger have decreed a matter that they should have any option in their decision. And whoever disobeys Allah and His Messenger, he has indeed strayed into a plain error" (Qur'an 33:36).

\footnotetext{
${ }^{1}$ Keylani 2015, 64 \& Yubi 1998, 36
} 
Every action we do in this life that sustains religion is worship, and the Muslim woman hopes that all her actions, sayings and doings, will bring her close to Allah, in order to fulfill and comply with the Statement of Allah the Almighty: "Say: O Muhammad: Verily, my prayer, my sacrifice, my living, and my dying are for Allah, the Lord of the all that exists" (Qur'an 6: 162).

Based on the above statement and report, the concept of the reality of working for a Muslim woman becomes clear. Both men and women know that they are charged with worshiping Allah, commanded to obey Him, and responsible in the Hands of Allah. As what the Prophet Muhammed, peace be upon him said: "The man is a shepherd for the people of his house, and the woman is a shepherd over the house of her husband and his children, so all of you are shepherds and each one of you are responsible for his flock" (Bukhari 732:5200).

\subsubsection{The Objective of Education and Advocacy of and Guidance to the Religion of Allah, Islam}

A woman teaching her children is considered a legitimate objective, so that the child is good and an asset for his nation, and for his parents benefit in this world and in the hereafter. The child in his childhood is prepared for education and guidance, so if he was raised on goodness, he will likely grow up on that, and he will be from the people of good and righteousness and goodness for his society. But if he was raised on evil, he will be miserable and everyone around him will be too. ${ }^{2}$

It is the legitimate duty of a woman to fulfil her educational mission in full, and to prepare her children to create the future of their nation and to be a good element in their surroundings with a merciful heart and a wise mind. The righteous mother who maintains the highest objective of the Sharia's objectives and the first of the five essentials, which is the preservation of religion.

In order to properly perform her educating role, it is imperative that she needs to obtain a good share of education. That is why wise women have not

\footnotetext{
${ }^{2}$ Ghazali 2014, 3/72
}

forgotten, since the age of the Prophets, about their right to learn and take and enjoy everything that is useful and beneficial to them. Religious science and propagation of religion (worship) of Allah were among the most remarkable achievements of the women and wives of the Prophet Mohammed, peace be upon him and his wives.

\subsection{The Second Necessity - The Objective of Self-Preservation}

\subsubsection{The Right to Self-Defense and to be Spared from Harm}

Some forms of women's self-care work include: Nursing, if necessary, to protect people from harm, for Sahih Al-Bukhari came from Alrobai' the daughter of Mo'ath who said that we were with the Prophet, peace and blessings of Allah be upon him, nursing and healing the wounded and bringing back the dead to Madinah during the state of war.

One of the applications of self-preservation related to women's work is the facilitation of giving birth. The presence of an obstetrician is a sufficient imposition on the communities that women are in, which is one of the necessities, because women who give birth to their children without the supervision of a doctor may face death or severe harm to themselves and their newborns.

\subsubsection{The Right to Breastfeed a Newborn}

The mother is obliged to breastfeed her newborn if the newborn does not accept breastfeeding from others, and she is sinning if she decided not to do it. This obligation centers on of preservation human life.

\subsubsection{The Right to Earn a Living}

The Muslim nation is built on the premise that it is the man who ultimately bears responsibility for spending, and the statements on this matter are concerted in Qur'an and Sunnah. If a woman's guardian is unable to spend, he has no right to prevent her from working and earning, and it is related to keeping herself and keeping others who are counting on her. As preserving oneself is one of the five necessities. Therefore, if it is a necessity for her to work, she should get a job. 


\subsection{The Third Necessity - The Objective of Preserving One's Intellect}

Islam honors the intellect, as it is the source of a person's capacity, so the Sharia safeguards it from all that harms it, including delving into what it does not benefit it or guide it aright.

One of the aspects of preserving one's mind in woman's work is that she is concerned with thinking about the Qur'an and understanding its meanings, following the example of "Aisha, may Allah be pleased with her, which she was frequently asking the Prophet about the meanings of the Qur'anic Verses, so she was able to interpret the Qur'an, and correct people's mistakes in their understating.

To preserve one's intellect, there are many and varied means, the most important of which is keeping it away from doubtful affairs and beliefs that lead to the corruption of one's sound beliefs based on the texts of the Qur'an and authentic Sunnah.

For a women with a sharp mind, understanding, and ability, she gets involved in public affairs such as counseling, educational guidance, scientific production, and other things that suit her nature and responsibilities.

\subsection{The Fourth Necessity - The Objective Preserving Money \& Property}

Islamic law urges us to earn and seek livelihood and forbids unneeded dependency and abandoning the means for acquisition of one's livelihood. It also obligated that each member of society, whether male or female, should seek the selfdependency for themselves and for their dependents, and it emphasized the rewards for doing so. Adding to that, Islamic law made woman's financial liability equal to that of men.

Among the purposes of women's work in trade and appropriate occupations and professions are: Refraining from the need of other people and maintaining her from moral deviations. If women were in need of others who are strangers to her, she will be afraid of being exploited in general, sexual exploitation in particular, which is evident in all human societies today.

\section{Taking into Account the General Goals} through Women's Work

\subsection{The First Necessity - Repelling Harm}

The rule of warding off harm is one of the rules of the purposes of Sharia, to serve the general purpose of the legislation, which is encouraging the interests of individuals and society as a whole and warding off evil and harm.

Pure harm is the same as the evil that must be avoided, and on this basis, the rules of Sharia preserve the necessary interests of people.

Consequently, all harm resulting from a woman's work is rejected in accordance with this rule, and only that which was in accordance with the nature that Allah created for her is accepted. As for the hard work which negatively affects the main focus of a woman, she is not allowed to perform it, due to being against the harmony of her nature.

And to her capacities, the Almighty declared: "Allah does not place a burden on a person greater than they can bear" (Qur'an 2:286). In addition, among the principles of our great religion, I have commanded the goodness of women, even in the field of work entrusted to them, and this is rooted in the Noble Qur'an and in the Prophetic Sunnah.

\subsection{The Second Necessity - The Reaching of Justice}

Justice is a general intention which applies to all the provisions, rules and principles of Sharia. It is the standard by which human behavior, problems and contracts are weighed, so that what is properly accepted will be accepted and what counters this will be rejected.

And justice in women's labour issues is represented by the preservation of their rights and the activation of their role in their nations without prejudice to their role in the family. Whenever their work leads to harming their main responsibilities, it is revised according to this principled point of view.

On this basis, we find that the tolerant Sharia settles between women and men in legal fees and financial responsibility, so there is no difference in the origin of the mandate between women and 
men in Islamic law. And this affirms to her the freedom to act and to conduct all contracts, without the least distinction between her and her opposite, in a way which guarantees her society an independent material autonomy according to the rules of Sharia.

\subsection{The Third Necessity - Taking into Consideration Wealth in Women's Work}

The consideration of wealth is a main concern on which many questions of knowing Sharia goals are based, because it has a purposive and realistic goal that aims to balance between bringing interest and warding off harm.

All the legal provisions relating to the work of women take into account this financial dimension of the rulings of the Sharia, because the Wise Legislator, Allah, has prevented all the means and excuses that lead to that which is prohibited, illegal, in Islam; such as the submission of women to the commands of men, because it leads to an increased desire of women in men, and therefore, Islam forbids staying alone with a foreign woman, one whom is eligible to be married, except with her having a guardian, one whom she is not eligible to marry, and travelling alone except with a guardian, to overcome the pretext of corruption and to protect from both types of Satan's ploys. From the looking at the end view of the results of a woman leaving her home towards a permissible matter of work, with or without a security guard with her on the way or at work, if it is feared that men may fall into temptation from her presence, then it is not permissible for her to leave her home in such circumstances. And this is why certain jurists dislike the departure of young women, fearing placing the men around them into temptation.

\subsection{The Fourth Necessity - Avoiding Difficulty \& Hardship}

Facilitating the objectives of one's life and avoiding difficulty and hardship is one of the purposes of Sharia law and one of its origins, because Allah the Almighty removed the hardship of this nation and only places a burden on them what they can bear. This rule is a feature of Islamic law and a manifestation of its grace.

One of the manifestations of Sharia and its merits is the permission of a woman to work, because of the help she gives to her father, mother, or husband, to earning a living and meeting her needs and the needs of those dependent upon her, and to refrain from asking others.

\subsection{The Fifth Necessity - The Legal Objectives of Women's Work}

Islam came to prioritize human life itself, stressing the need to place things according to their priority and their importance, linked to the individual or the group; according to this legal consideration of prioritization, the work of women is regulated to be organized according to realizing the confirmed legal principles, and they are adjusted by:

\subsubsection{The Balance Between Work and Obedience to the One in Charge}

The obedience of a woman to her husband in permissible manners is an unadulterated legal right, and it is obedience to Allah first and foremost and then obedience to her created husband in order to seek the Pleasure of Allah the Almighty. Therefore, jurists require the permission of the woman's guardian for a woman to leave the house to work or otherwise. In light of these legal directives, and taking into account the need and facilitation of doing so, a woman must choose a job that enables her to carry out her responsibilities, so she does not violate the rights of the husband if she is a wife, or the rights of her children, or the rights of her work over herself if the work is strenuous to her body, or affects her beauty, then she should not choose such work. This is one of the rights indicated by the general hadith: "Indeed your Lord has rights over your body has a right over you and your family have rights over you, so give everyone who has a right his right" (Bukhari 3-38:1968).

\subsubsection{The Purpose of Education and Responsibility}

The true religion of Islam is keen on taking care of children, raising them with good education, and 
nurturing and disciplining them with the etiquettes of Islam, as education is a trust and responsibility, most of which falls on the woman because of the statement of Prophet, peace be upon him: "The woman is a shepherd over the house of her husband and his children, so all of you are shepherds and each one of you are responsible for his flock" (Muslim 1829 \& Bukhari 6719).

Accordingly, if the requirements of work contend with their family and social requirements, they follow the scale of priorities in favoring the most important and then the next, and raising children is at the top of these priorities, if they contradict the work in question then they are given preference.

It is not understood that a woman is deficient in relation to a man's work, but the issue is a balance of priorities that the wise Legislator, Allah, considered; for women and men were created to live and contribute in their environments, and everyone works in their individual positions for the greater whole.

7. The Goals of Sharia Related to Women's Work

Jurisprudence with partial purposes is a characteristic of established scholars, as it contributes effectively in evaluating the work of women and directing them to the right and rational direction on one hand, and in the avoidance of suspicion and harm on the other; which is something that we urgently need in the present day in the presence of those who divorce easily and those who conceal their faults in eyes of the public.

The partial purposes of women's work can be presented in the following requirements:

\subsection{The First Requirement - The Purpose of Goodness and Beneficence to the Husband and the Family}

The rights of the spouses on each other: the beneficence of each of spouse to the other, and the avoidance of harming each other, because that is of the goodnesses of Islam, and it is a kindness, a mercy, and from good manners encouraged by the Sharia. One of the manifestations of a woman's beneficence in her dealings with her husband is relieving the husband of bearing some of the household's workload, and the role model for women in that is Asmaa bint Abi Bakr, may Allah be pleased with him, who said:

When Az-Zubayr married me, he had neither land, nor wealth, nor anything except a camel to get water and a horse. I used to graze his horse, provide fodder for it, look after it and grind dates for his camel and drew water for it and patched up his leather bucket, and kneaded the dough for bread and I was not very good at baking so neighbors from the Ansaar baked it for me and they were sincere women. And I used to carry on my head the date-stones from the land of AzZubair which the Prophet, peace be upon him, bestowed him with, and it was a distance of three miles from Madinah (Bukhari 7-35:5224).

Relieving the husband of bearing some of the household's workload has great legitimate purposes that are reflected in the increased affection and mercy between spouses, the honoring of the husband and children, strong family bonding, deepening love between family members and relatives, and above all, it has the reward of giving charity to one's loved ones and the reward of worship to Allah.

\subsection{The Second Requirement - Independency and Doing Good}

A woman earning money in legitimate ways is one of the established purposes in the Sharia, as it is a way to obtain permissible money, and accordingly maintains herself from being in need of people.

Independency of one's children and relatives that one spends upon, refraining them from asking others and from the charitable donations of others, in addition to that, contributing to charitable works and righteousness and benefiting the community, and its evidence is the hadith of Jabir bin Abdullah, may Allah be pleased with him, that his aunt was an owner of many palm trees.

The Prophet, peace be upon him, gave her permission to work and spend, and he said: 'Yes, profit from your palm trees, for perhaps you may 
give in charity or do good others by doing so' (Muslim 19:3721).

\subsection{The Third Requirement - Modesty and Chastity}

Muslim women seek and strive for goodness, and all goodness is in that which Allah has ordained in His Sharia, Glorified and High is He. To be great and a means of good, not as a route for evil. The woman with her commitments stops at the limits of the Prophet's saying, peace be upon him: "Modesty is all good" (Muslim 1-64:60), and she bears by this, great manners.

What helps a woman to retain her modesty while working is: Avoiding mixing with other men, because it is purer for their hearts, and distances one from suspicion; unlike mixing with men, which leads to great evils, and if it was for the demise of the woman's modesty and encouraging in her boldness when dealing with men, that would be sufficient enough means to prevent her working.

In the story of the daughter of Shoaib, peace be upon him, is an example to work with the morality of modesty and the avoidance of mixing with other men. Muslim women who work should imitate the two noble women found in the Statement of the Almighty:

And when he came to the well of Madyan, he found there a crowd of people watering [their flocks], and he found aside from them two women driving back [their flocks]. He said, 'What is your circumstance?' They said, 'We do not water until the shepherds dispatch [their flocks]; and our father is an old man' (Qur'an 28:23).

\subsection{The Fourth Requirement - Stability in the Family Home}

The basic foundation for woman is to stay at the home except for a specific need, and her work outside her home is an exception to this basic principle. Her primary mission is to take care of her family, a nanny for her children, and the Sharia guarantees her, that her staying in her home is a measure of honor and dignity, and that it provides support and comfort to her husband, and it guides her to leave some of the duties that require one going out, such as prayer in congregation, striving for the Sake of Allah, and Hajj if she does not have anyone to go with.

\subsection{The Fifth Requirement - Solidarity, Cooperation and Meeting the Needs of Society as a Whole}

Sharia made the woman, by principle, someone who is maintained financially, and urged spending on her in the absence of the breadwinner of the family, especially if she had orphans, as in his saying: "The one who seeks to maintain the widow and the poor is like the fighter in the way of Allah" (Bukhari 7-62:5353).

A woman works and contributes to social solidarity, but at the same time does not leave her main concerns, but she contributes to society in general and financial aid is eligible for her when the breadwinner is absent, whether it is a husband, father, or brother. As such, the financial burdens in our times are heavy that many men, as well as women, carry.

\section{Conclusions}

The researcher believes that women's work is an essential necessity in the principles of Sharia, and for this reason he conducted the study with a view of the goals of Sharia, and of that study he concluded the most notable results:

1. Women's work is a part of community participation that is regulated by Sharia.

2. The woman, in her work, considers the purpose of such work as worship to Allah the Almighty.

3. A sane woman adopts her work dealings on a valid scientific basis.

4. The work of women covers essential life rights such as the enjoying of good health and education, among other aspects of life.

5. A woman's work contributes to the protection of herself and her children from financial and moral problems and from social hardships.

6. A woman's financial liability is equal to that of a man. 
7. Women are prohibited from carrying out work that harm their bodies or their main responsibilities, or that lead to undesired earnings, such as those earned through the mixing with other men, or being alone with men or traveling alone.

8. Muslim women have contributed to the service of society since the time of Prophethood.

9. Priorities, legislated by the Sharia, must be taken into consideration when women work outside the home.

In terms of recommendations, the researcher sees the necessity to expand the research into the Sharia goals related to women in general, as from them is one's mother, sister, daughter, grandmother, aunt and stepdaughter, and so on, and each one has a special set of circumstances that are associated with the general descriptions of women, and it is important to study these specific descriptions within the guidelines of the goals of Sharia, and to clarify current Islamic rulings based on such.

\section{Acknowledgement}

This project was supported by the Deanship of Scientific Research at Prince Sattam bin Abd-ElAziz University under research project No 2019/02/10675.

\section{REFERENCE}

[1] Abdulaziz bin Baz, (1413/1992). Adorning in Public and its Dangers [Altabarrug wa Khotoratoh] (Saudi Arabia: Minstry of Islamic Affairs)

[2] Abdulbaqi M. F, (1431/2010). As-Sahih Muslim (Beirut: Ihiaa Alturath)

[3] Abdulsalam, H. (1421/2000). Metophors in the Arabic Language [ Majaaz Allugha] (Damascus: Dar Alfikr)

[4] Abouti and Saed, (1st ed.) ( 1438/2017). Almra'ah bin tughyan alnatham algharbi waltaa'f altashria' alrbani (Dimuscus: Dar Alfikr)
[5] Alhazmi K, (1420/1999). Handbook of Islamic Education (Book World)

[6] Al-Ez ibn Abdul-Salam, (1436/2015). Qawai'd Al-Ahkam Fi Masalih Alanam (Cairo: Library of Al-Azhar Colleges)

[7] Alshatibi, (1432/2007). Al-Mowofikaat (Beirut: Dar Almaarifa)

[8] Badr Eldin Alaini, (1422/2001). Sahih Albukhari (Beirut: Dar Ihiaa Alturath Alarabi)

[9] Council of Fatawaa, (1431/2010). Majmoo' al-Fatawa (KSA)

[10] Ghazali M. (4 ${ }^{\text {th }}$ ed.) (1435/2014). Reviving the Sciences of the Religion [Ihya' Ulum al-Din] (India: Islamic Book Service)

[11] Keylani A, (4 ${ }^{\text {th }}$ ed.) (1434/2015). In Criticism of the Definition of the Objectives of Sharia: Principles of the Objectives [Intqd AlMaqaasid Asharea': Qawaaid AlMaqaasid] (Damascus, Dar Alfikr)

[12] Ibn Qayyim, (1 ${ }^{\text {st }}$ ed.) (1435/2014). I'lam al-Muwaqqi'in 'an Rabb al 'Alamin, (Beirut: DKI)

[13] Imam al-Shafi'I, (1432/2011). The Mother Book [Kitab al-Umm] 11 vol. (Beirut: Dar ibn Hazm)

[14] Ibn Katheer, ( 1435/2014). The Beginning and The End [albidayah wanniyaha] (Beirut: DKI)

[15] Ibn Kodama, (1417/1996). Almughni (Beirut: Alam Alkotob)

[16] Imam Muslim, (1414/1973). The Methodology of Sahih Muslim [Almanhaj Sahih Muslim] (Beirut: Ihiaa Alturath)

[17] Ibn Hajar al-Asqalani, (1379/1982). Sahih Abukhari (Beirut: Dar Amaarifa)

[18] Imam Qurtubi, ( $2^{\text {nd }}$ ed.) (1384/1965). Tafseer Al-Qurtubi, (Egypt: Egyptian Publishing House)

[19] Ibn Hisham, (1374/1955). The Prophetic Path [Sirah al-Nabawiyah] (Egypt: Mustafa Alhalabi and Sons Publishing House) 
[20] Ibn Qayyim al-Jawziyyah, (1 ${ }^{\text {st }}$ ed.) (1431/2010). [Alturoq Alhakeema] (Dar Albayan library)

[21] Imam Albukhari, (1 ${ }^{\text {st }}$ ed.) (1422/2001). Sahih Albukhari, (Dar Towg Alnaga)

[22] Malik ibn Anas, (1 ${ }^{\text {st }}$ ed.) $1416 / 1995$ Almudawana (Dar Alkotob Al-Elmya)

[23] Yubi M. (1 ${ }^{\text {st }}$ ed.) (1419/1998). The Objectives of the Sharia [Qawaaid Asharea] (KSA: Dar Al-Hijra for Publication) 